\title{
DIGITAL LIBRARY DEVELOPMENT IN AUSTRALIA
}

\section{$\underline{\text { ABSTRACT }}$}

This paper will present results of a survey that was conducted during the winter and spring of 2014. The participants are librarians that have a digital library or institutional repository within the institution they serve. The questionnaire asks both qualitative and quantitative questions regarding the following:

- About what kind documents are in the collection?

- How is the library staff marketing the collection?

- Who is the target market or audience?

- What kind of information sharing is happening with the university?

- Basic demographic information

The survey was mediated by Survey Monkey and the participants was sent the link via email.

Digital library development in Australia began with a government initiative in the early 2000s. Mary Anne Kennan and Danny A. Kingsley (2009) had looked at the state of institutional repositories as of September 2008. The authors found varying universities at different states of repositories (Kennan \& Kingsley, 2009). Some of the universities were entrenched; others had barely started to begin the repository process beginning in 2008 .

The mandate continued with the requirement for repositories at academic libraries under the Excellence for Research for Australia (ERA) to support open access (Harvey, 2008 as cited by Kennan \& Kingsley, 2009). The academics needed to supply copies of their articles or conference proceedings to their academic library in order for a copy of the file to be submitted to ERA during the review of the reference period.

Previous to this, academic libraries in Australia had undertaken different levels of repositories mainly with the view of offsite storage of the print collections. According to Genoni $(2007,2008,2012)$ the Victorian and South Australian universities were some of the first to collaborate and have co-located offsite storage. The holdings would be available to the patrons via the OPAC and there would be a 24 hour turnaround in order to bring the book back to campus for check out. While this is a repository per se, this is not a digital one.

Our study will look at digital libraries in Australia. As Kennan and Kingsley's study occurred in 2008, this should be a good time to do an updated environmental scan of Australia. Along with looking at digital libraries, we are interested in if anyone is using the digital libraries that have been set up. If there only a few users, this begs the question what kind of marketing is being done at the digital libraries. This survey will look at both the types of records the digital library is archiving and the type of marketing that is being done to let people know the information is being kept at the repository. 


\section{INTRODUCTION}

The paper has three purposes: to give an overview of the Australian digital collections as they stand today; discussion of the marketing of digital collections tied to a pilot study that the authors have undertaken and finally, to discuss assessment and evaluation of what users' desire in a digital collection. The study focuses primarily on developers using open source software, primarily used by institutional repositories. The software is being adopted by a wide range of libraries and cultural institutions, academic, government and cultural. Once the library has content digitally the question then becomes who are your users? Most of the literature is most concerned with the development and implementation of the digital libraries. There is very little literature on the marketing of the collections once they are built. The marketing of the digital library is as important as building it. The underlying concept to quote the movie Field of Dreams (2004), "build it, they will come" seems to be the ideal but it appears that very little time, money, or effort is given to make sure they do come. In order to find out if appearances are true we put together a survey on the marketing of digital libraries.

\section{Australian Digital Libraries}

For this paper, digital libraries encompass institutional repositories (IR), archives, and collections of various types. A digital IR has on deposit documents from academics and students. According to Clifford Lynch, "an institutional repository is . . . a set of services that a university offers to the members of its community for the management and dissemination of digital created by the institution and its community members" (Lynch, 2003, p. 2).

The most common type of deposit is theses and dissertations that have been accepted as completed by students graduating with their bachelors' honours, masters, or PhD. Many times academics will deposit pre-print or post-review articles that will be published by journals in the various disciplines. Many of the universities in Australia have begun to mandate that all articles that are submitted for publication must be deposited. This is due to the Australian government's use of Higher Education Research Data Collection (HERDC) reporting. Australian Research Council (ARC) administers the Excellence in Research for Australia (ERA) "which aims to identify and promote excellence across the full spectrum of research activity in Australia's higher education institutions" (ARC, 2014). In fact, ARC requires each higher education university to have an IR for academics to deposit their research publications.

IRs are just one type of digital library and may have other types housed within the library like an archive or special collection. National and state libraries may also have digitized collections available for citizens to access via the internet as not everyone can get to a physical space. While public libraries have historical documents and newspapers in their collections, they tend to be caught in a catch-22 where it is expected they will digitize their collections but many times the funding is not forthcoming. This situation is oftentimes called an "unfunded mandate" (Velasquez, 2009, p. 3272). Additionally, major public libraries may have "competing mandates for cultural preservation, access and service provision, and resource efficiency" (McShane \& Thomas, 2010, p. 155). In order to do any of those mandates well takes strategic planning that is tied to their parent organization's mission and vision. Public libraries also have to compete for funds with police, fire, parks, recreation, public works, and other departments that may appear more 
important in the scheme of things to those doling out the money. The whole concept of public good sometimes gets lost as defined in the theory of political economics. Johnson (2005) defined a public good as "a very special class of goods which cannot be withheld from all and for which the marginal cost of an additional person consuming them, once they have been produced, is zero". Many of the councils find that public libraries are some of the most popular with the public who visits them but that does not always endear them to the mayor and council.

\section{Marketing of Digital Collections}

What each type of digital library or institutional repository has in common is that it needs to have visitors to make it viable. Librarians have used various methods and techniques of marketing in order to influence faculty and visitors to come to the web site and use the digitized materials and records. According to Kennedy (2011) some of the types of techniques included internal and external email, online social networks, screen savers, usage statistics, web page alerts, bookmarks, banners, posts, calendars, brochures, giveaways, newsletter, direct mail, patron training, staff training, faculty/professionals as marketing tools, phone calls, surveys, and word of mouth. The previous list is by no means the entire list included in Kennedy's article but just an example of some of the techniques and methods used by digital libraries. She goes on to make the point that there is no one particular method preferred by any type of digital library but they all try different things according to their theoretical bent (Kennedy, 2011). Kotler and Levy's (1969) seminal work makes the point that in order for marketing to be effective it requires a customer orientation instead of product orientation still holds true. In our study we are interested in how the different types of digital libraries staff have used marketing in order to get their target audience involved in their collections.

\section{Assessment and Evaluation of Digital Libraries}

As with any project, clear evaluation and assessment measures should be in place before a project starts. When a project is evaluated, a decision is made about whether it met the stated goals and objectives and whether the outcomes were successful or not. As repositories develop, managers collect qualitative and quantitative data about a repository's services and collections to see if the service is meeting the needs of the community or organization it serves. Campbell-Meier (2011) identifies the need for both qualitative and quantitative measures for repository assessment. Through case studies, she documents IR developers noting that there "...are benefits in developing and maintaining an IR, but the difficulty lies with defining them, describing them, and actually confirming that [the benefits] are happening" (pp. 172-173).

Saracevic (2000) identified six dimensions for evaluation: content, technology, interface, service, users, and context. Fuhr et al. (2007) and Zhang (2010) discuss the development of holistic evaluation models for digital libraries. Fuhr et al. discuss the need for flexible measures, involved users and the development of a digital library research community. Zhang proposes a model based on Saracevic's evaluation dimensions. Evaluation criteria are developed by the type of user as well as the specific level or area. Both models include information seeking behaviour as part of the evaluation process. 


\section{METHODOLOGY}

The research used a mixed methods questionnaire that contained 37 questions sent to an international group of digital collection managers and developers identified from the Registry of Open Access Repositories (ROAR). The survey was conducted on Survey Monkey. At this point, it is a pilot study as we have 29 responses. We are continuing to send out requests to take the survey to eligible parties in digital libraries and institutional repositories.

The survey asked questions about digital collections, attempting to determine the size and scope of the collections, and what the user experience is in using the collection. We are also interested in current marketing practices the digital libraries are using to get users to the web site. There were some basic demographic questions asked regarding what country the respondent was from as well as gender, age, education, and role in the digital library.

\section{$\underline{\text { RESULTS }}$}

\section{Size and Scope of the Collections}

Given the small sample size that we currently have in the pilot study, the size of the collection are at two ends of the spectrum either less than $10,000(9,39 \%)$ or more than $50,000(5,22 \%)$ with the remaining falling in between those sizes $(9,39 \%)$. The majority of the collections had the following:

Table 1. What does your collection primarily contain?

\begin{tabular}{|l|r|r|}
\hline Answer & Number & $\%$ \\
\hline Historical Records & 14 & $61 \%$ \\
\hline Images & 11 & $48 \%$ \\
\hline Organizational Records & 10 & $44 \%$ \\
\hline Scholarly Communication & 18 & $78 \%$ \\
\hline Sound Recordings & 9 & $39 \%$ \\
\hline Video Recordings & 10 & $43 \%$ \\
\hline Other: Greek \& Latin Texts, Theses \& & 3 & $14 \%$ \\
Dissertations, Data sets and GIS & & \\
\hline
\end{tabular}

Note: Will not total $100 \%$ as respondents could choose multiple answers.

Table 2. What type of material is primarily represented in your collection?

\begin{tabular}{|l|r|r|}
\hline Answer & Number & $\%$ \\
\hline Documents & 22 & $96 \%$ \\
\hline Images & 7 & $30 \%$ \\
\hline Sound Recordings & 5 & $22 \%$ \\
\hline Video Recordings & 6 & $26 \%$ \\
\hline Data sets & 4 & $17 \%$ \\
\hline Other: Power Point slides & 1 & $4 \%$ \\
\hline
\end{tabular}

Note: Will not total $100 \%$ as respondents could choose multiple answers.

Table 3: Categorization of Digital Library Collection

\begin{tabular}{|l|r|r|}
\hline Answer & Number & $\%$ \\
\hline Archival & 11 & $50 \%$ \\
\hline Government & 0 & $0 \%$ \\
\hline Historical & 12 & $55 \%$ \\
\hline Institutional (university or college) & 20 & $91 \%$ \\
\hline Subject & 8 & $36 \%$ \\
\hline Corporate & 0 & $0 \%$ \\
\hline
\end{tabular}




\begin{tabular}{|l|r|r|}
\hline Other: Government & 1 & $5 \%$ \\
\hline
\end{tabular}

Note: Will not total $100 \%$ as respondents could choose multiple answers.

\section{$\underline{\text { Users }}$}

In order to determine how to market to the users of the digital library, one needs to know who the users are - theoretically. The question was asked on the survey. There was quite a range of answers as it was qualitative but it could be narrowed down into three answers: don't know (12), staff and students of their own university (6), and researchers and scholars (3). The answer to this question was surprising as it made it very obvious even in such a small sample that these digital library managers and librarians were unaware of who was using their digital library and didn't appear to care.

The participants were asked how many documents were downloaded from their site in June 2014. There were four that did not know as they did not keep track. The rest of the answers were primarily in the 1,100 to 30,000 documents downloaded. There were three outliers that were $102,228,337,487$, and 500,000 . There was also one at 41,000 .

The question asked about how many users they had visiting their digital library site. There was one that didn't track individual users and two that didn't know. Again, not tracking users was perplexing as it seems vital to know how many users you have at your site at any given time. The definition of user was those who accessed, browsed, or downloaded documents and materials.

Figure 1. On average, how many users visit your repository each month?

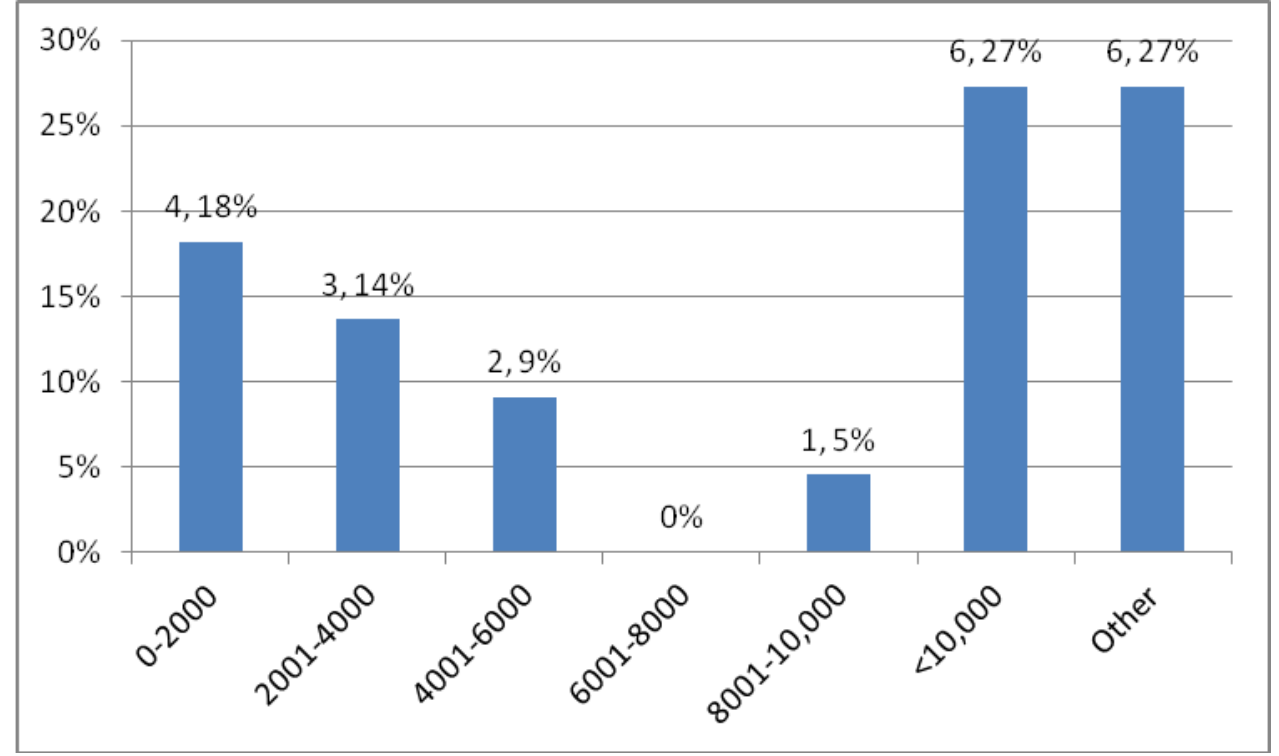

There was a group of questions where the respondents were asked to consider different aspects about their users on a Likert-like scale. The question started with:

"Please use the following scale to indicate the extent of agreement about how well each of the following statements is an accurate description of your organization's relationship with its users."

Table 4: Organization's Relationship with its Users 


\begin{tabular}{|l|c|c|c|c|c|c|c|c|c|c|}
\hline & $\begin{array}{l}\text { Strongly } \\
\text { Disagree }\end{array}$ & \multicolumn{2}{c|}{$\begin{array}{c}\text { No } \\
\text { Disagree }\end{array}$} & \multicolumn{2}{c|}{$\begin{array}{c}\text { Nopinion } \\
\text { Agree }\end{array}$} & \multicolumn{2}{c|}{$\begin{array}{c}\text { Strongly } \\
\text { Agree }\end{array}$} \\
\hline $\begin{array}{l}\text { We frequently and systematically } \\
\text { monitor the needs of our users }\end{array}$ & $18 \%$ & 4 & $27 \%$ & 6 & $9 \%$ & 2 & $41 \%$ & 9 & $5 \%$ & 1 \\
\hline $\begin{array}{l}\text { We get ideas about new } \\
\text { products and services from our } \\
\text { users }\end{array}$ & $14 \%$ & 3 & $36 \%$ & 8 & $5 \%$ & 1 & $41 \%$ & 9 & $5 \%$ & 1 \\
\hline We regularly talk to our users & $19 \%$ & 4 & $19 \%$ & 4 & $10 \%$ & 2 & $43 \%$ & 9 & $10 \%$ & 2 \\
\hline $\begin{array}{l}\text { We regularly evaluate users' } \\
\text { preferences }\end{array}$ & $14 \%$ & 3 & $32 \%$ & 7 & $9 \%$ & 2 & $36 \%$ & 8 & $9 \%$ & 2 \\
\hline $\begin{array}{l}\text { We regularly discuss our users } \\
\text { needs }\end{array}$ & $9 \%$ & 2 & $18 \%$ & 4 & $9 \%$ & 2 & $50 \%$ & 11 & $14 \%$ & 3 \\
\hline
\end{tabular}

\section{Marketing}

The rest of the survey looked at how the digital library was being marketed to the users. There was a range of answers supplied but not everything was considered.

Figure 2. Marketing of Digital Library

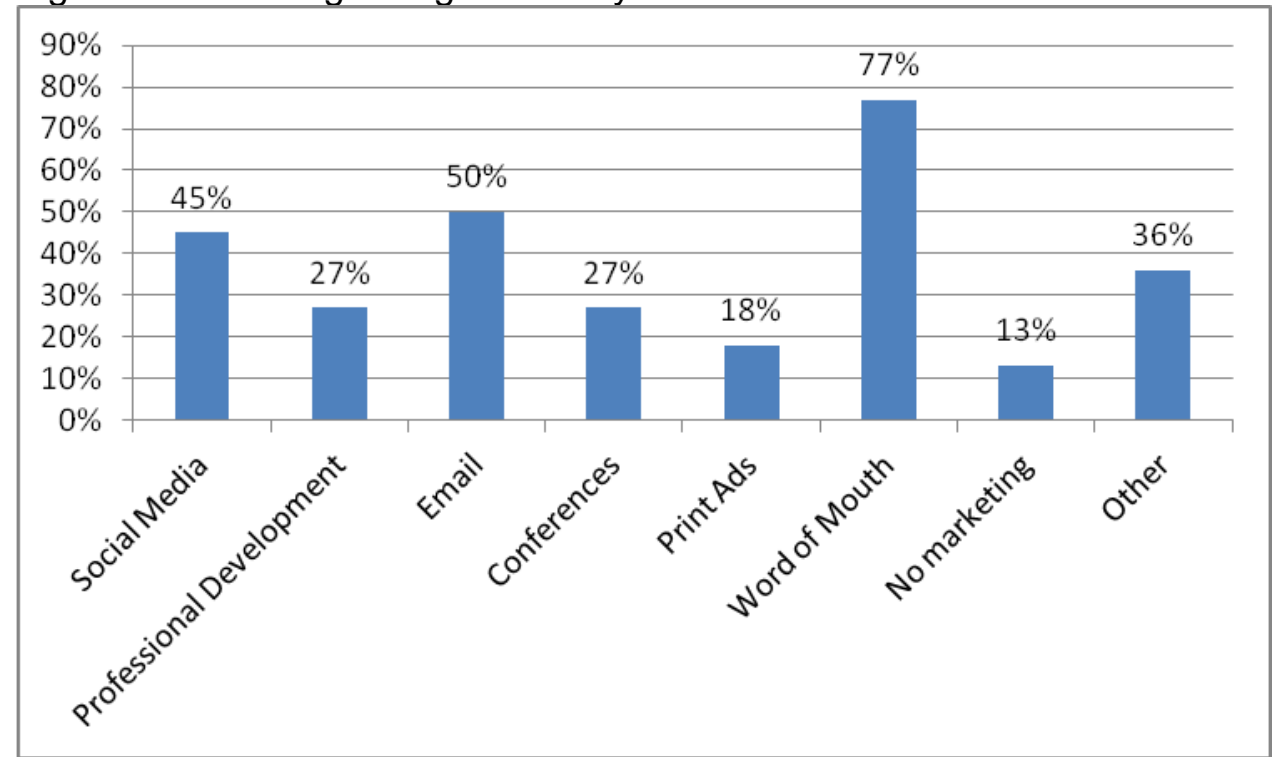

Note: Will not sum to $100 \%$ as respondents could choose multiple answers.

The other category answer consisted of websites, Google, Wikipedia, subject librarians, graduate workshops, and marketing to internal clientele like academic staff within the university.

When money was considered the majority of the digital libraries $90 \%$ (18) of the 20 answering had no budget for marketing. This aspect was amazing. The whole idea of putting up a $\$ 100,000$ plus for a digital library considering the software, the staff, and the time to put it together and then there is no money to market the whole concept. When asked how much the budget was the majority either said zero or had no idea. One came up with a figure of $\$ 100$.

The survey asked a group of questions about the functional value of marketing the digital library collection. The majority of the answers were "no opinion." The next group of questions were about the professionalism of those marketing the digital library collection. Again, the majority of the answers were "no opinion." When asking about the quality of marketing of the digital library, the answers were "no opinion" by 
the majority. The group of questions about the cost of marketing gain had the highest "no opinion" answers of the marketing questions. The last group of marketing questions asked attitudinal questions about marketing and the group, for the most part, had no opinions.

\section{Evaluation and Assessment}

Fifty percent of respondents do not have assessment measures in place for their digital library collections. As discussed in the literature review, it is difficult to develop assessment measures for a growing or developing collection. Holistic models of evaluation assess use as well as service. Measures may change over a projects lifetime; however, it is difficult to gauge success without benchmarks of some kind.

Table 5. Do you have assessment measures in place for the digital library collection?

\begin{tabular}{|l|r|}
\hline $\begin{array}{l}\text { Yes, we have identified goals for digital collection and collect specific } \\
\text { metrics to measure our progress }\end{array}$ & $27 \%$ \\
\hline Yes, we collect specific metrics, but do not have specific goals & $23 \%$ \\
\hline No, but we are developing assessment measures & $18 \%$ \\
\hline No, we do not have assessment measures & $37 \%$ \\
\hline
\end{tabular}

Respondents were also asked about evaluation measures. Respondents were asked to check all of the metrics they currently collected and had an opportunity to write in additional measures. While the quantitative data measured may provide a basic benchmark for the collection, the information provided does not explain how or why a collection is being used.

Table 6. What metrics do you collect to evaluate the collection? Check all that apply

\begin{tabular}{|l|r|}
\hline Number of items added & $100 \%$ \\
\hline Number of items downloaded & $80 \%$ \\
\hline Number of items viewed & $40 \%$ \\
\hline Number of authors & $40 \%$ \\
\hline Number of new collections (Other) & $20 \%$ \\
\hline Number of views of recently included items (Other) & $10 \%$ \\
\hline Number of accounts created & $10 \%$ \\
\hline Number of searches & $0 \%$ \\
\hline
\end{tabular}

\section{Demographics}

The majority of the respondents had information science backgrounds. The respondents could choose more than one answer under the degree answer so the answers were as follows:

Table 7. Participant's Education

\begin{tabular}{|l|r|r|}
\hline Degree & Number & $\%$ \\
\hline Bachelors with LIS concentration or focus & 2 & $10 \%$ \\
\hline Bachelors degree & 14 & $70 \%$ \\
\hline MLIS, MLS, MIM or equivalent & 12 & $60 \%$ \\
\hline Masters in another field & 5 & $25 \%$ \\
\hline PhD in LIS or CIS related field & 0 & $0 \%$ \\
\hline PhD in another field & 2 & $10 \%$ \\
\hline JD & 0 & $0 \%$ \\
\hline
\end{tabular}




\begin{tabular}{|l|r|r|}
\hline $\begin{array}{l}\text { Other: Diploma in Library and Information } \\
\text { Technology }\end{array}$ & 1 & $5 \%$ \\
\hline
\end{tabular}

Table 8. Participant's Age

\begin{tabular}{|l|r|r|}
\hline Age & Number & $\%$ \\
\hline $21-29$ & 3 & $15 \%$ \\
\hline $30-39$ & 5 & $25 \%$ \\
\hline $40-49$ & 8 & $40 \%$ \\
\hline $50-59$ & 3 & $15 \%$ \\
\hline 60 or older & 1 & $5 \%$ \\
\hline
\end{tabular}

The gender of the participants was $50 \%$ male and $50 \%$ female.

\section{$\underline{\text { Conclusion }}$}

Repository managers should use qualitative and quantitative measures for inputs, processes, outputs, outcomes to evaluate and improve repository systems and services. Some of the metrics used may be important for benchmarking. Assessment and evaluation are part of an iterative process and must be revisited throughout the life of a digital collection.

Users are important. The librarians and collection managers should pay attention to them. Marketing the digital collection is also important. The idea that putting up the website for the digital content is enough to get users to find it is ludicrous. The marketing of any product or service takes time and effort. If the library staff (whatever the type) is not willing to put forth the effort to market the service, then there will be no users outside of the local community (students, academics, etc.). The digital library willing to spend some money on marketing will be the one that will see the biggest gains in user downloads and users coming from outside of their community. 


\section{$\underline{\text { REFERENCES }}$}

Australian Research Council (ARC), Commonwealth of Australia. (2014). ERA 2015. Retrieved from http://www.arc.gov.au/era/

Campbell-Meier, J. (2011). A framework for institutional repository development. Advances in Library Administration and Organization, 30, 151-185.

Fuhr, N. et al. (2007). Evaluation of digital libraries. International Journal on Digital Libraries, 8(1), 21-38.

Genoni, P. (2007). Towards a national print repository for Australia: Where from and where to? Australian Academic \& Research Libraries, 38(2), 84-98. DOI: 10.1080/00048623.2007.10721279

Genoni, P. (2008). Current and future print storage for Australian academic libraries: Results of a survey. Library Collections, Acquisitions, \& Technical Services, $32,31-41$.

Genoni, P. (2012). Storage of legacy print collections: The views of Australasian university librarians. Collection Management, 37(1), 23-46. DOI: 10.1080/0142679.2012.629407

Jantz, R. C., \& Wilson, M. C. (2008). Institutional repositories: Faculty deposits, marketing and the reform of scholarly communication. The Journal of Academic Librarianship, 34(3), 186-195.

Johnson, P. M. (2005). A glossary of political economy terms. Retrieved September 27, 2005, from http://www.auburn.edu/ johnspm/gloss/public goods

Kennedy, M. (2011). What are we really doing to market electronic resources? Library Management, 32(3), 144-158. DOI: 10.1108/01435121111112862

Kennan, M. A., \& Kingsley, D. A. (2009). The state of the nation: A snapshot of Australian institutional repositories. First Monday, 14(2). Received from http://firstmonday.org/ojs/index.php/fm/article/view/2282/2092

Kotler, P., \& Levy, S. J. (1969, January). Broadening the concept of marketing. Journal of Marketing, 33(1), 10-15.

Lynch, C. (2003). Institutional repositories: Essential infrastructure for scholarship in the digital age. ARL Bimonthly Report, No. 226. Available at www.arl.org/bm doc/arl-br-226.pdf

McShane, I., \& Thomas, J. (2010, June). Unlocking the potential? Australia's digital strategy and major public libraries. Prometheus, 28(2), 149-163. DOI: 10.1080/0810928.2010.496235

Robinson, P. A. (Director, Writer). (2004). Field of dreams. University City, CA: Universal. [Motion picture].

Saracevic, T. (2000). Digital library evaluation: Toward an evolution of concepts. Library Trends, 49(3), 350-369. 
Velasquez, D. L. (2009). E-Government and public access computers: A national survey of practices. Madrid, Spain: Conference CD for International Conference of Education, Research, \& Innovation (ICERI), pp. 3272-3281.

Zhang, Y. (2010). Developing a holistic model for digital library evaluation. Journal of the American Society for Information Science \& Technology, 61(1), 88-110. 